\title{
Theory and practice of mathematics teacher education: An explorative study at the department of mathematics education, Indonesia University of Education
}

\author{
Al Jupri \\ Departemen Pendidikan Matematika \\ Universitas Pendidikan Indonesia \\ Bandung, Indonesia \\ aljupri@upi.edu
}

\author{
Tatang Herman \\ Departemen Pendidikan Matematika \\ Universitas Pendidikan Indonesia \\ Bandung, Indonesia \\ tatangherman@upi.edu
}

\begin{abstract}
This article reports on results of a survey on the theory and practice of mathematics teacher education program carried out at the Department of Mathematics Education, Universitas Pendidikan Indonesia (Indonesia University of Education), Bandung, Indonesia. The data were collected through questionnaires and interviews to nine selected lecturers and to 90 undergraduate students of mathematics teacher education program. Three main results on best practices in preparing prospective mathematics teachers are addressed in this article: Teaching and learning processes, assessment of student performance, and student feedback on the practices of mathematics teacher education program.
\end{abstract}

Keywords-teacher professional development; Mathematics teacher education; mathematics teachers; Indonesia.

\section{INTRODUCTION}

Established officially in 1963, the Department of Mathematics Education is recognized as one of the oldest departments at the Universitas Pendidikan Indonesia (Indonesia University of Education), and even in Indonesia. Since then this department has produced alumni whose expertise in the field of mathematics education, mostly work as mathematics teachers in particular.

In Soeharto era (1966-1998), the challenges faced by the department were, inter alia, to produce a large number of mathematics teachers for schools all over Indonesia. In the reformation era and since the Law of Teachers and Lecturers were released in 2005 [1], the challenges faced by the department have increased and more complex: not only producing a number of mathematics teachers, but also developing more qualified teachers. According to the Law, a teacher should have four general competencies: Pedagogical, Professional, Social, and Personality competencies. These four competencies are real challenges that should be dealt with.

With the above challenges, the department of mathematics education has carried out creative innovations to fullfill the demand. So far, even if other challenges rise and fall, the department has succeeded. The alumni have spread all over Indonesia and are recognized as qualified teachers ([2], [3]). Considering this, we wonder about the implementation of mathematics teacher education in this department: how the learning and teaching processes are carried out, how prospective mathematics teachers are assessed to guarantee qualified alumni, and what are best practices that we can learn from to prepare future mathematics teachers. As initial steps to deal with these questions, we, - under a bigger international collaborative research project entitled, "Best Practices in Mathematics and Science Teacher Education in Selected ASEAN Countries" - conducted an explorative study to investigate the implementation of mathematics teacher education program at the Department of Mathematics Education, Indonesia University of Education.

For the purpose of this study, we use Productive Pedagogy as a framework for designing, analyzing and interpreting the study. Productive Pedagogy provides an analytical framework for a model of teaching practice that can be applied in the preand-in service teachers [4]. In general, the Productive Pedagogy includes four dimensions: Intellectual quality, connectedness, supportive classroom environment, and recognition of difference ([4], [5]]. Each dimension provides a comprehensive description about teaching practice.

The intellectual quality dimension includes five items: higher order thinking, deep knowledge, deep understanding, substantive conversation, knowledge as problematic, and metalanguage. Key questions addressed in these items include, inter alia, are higher order thinking and critical analysis occurring? Does the lesson address fields in any depth and detail? And do the work of students provide evidence of understanding of concepts?

The connectedness dimension includes four items: Knowledge integration, background knowledge, connectedness to the world, and problem based curriculum. Key questions in these items include, for instance, does the lesson range across diverse fields and disciplines? Are the lessons and tasks connected to real-life contexts? Is there a focus on solving real-world problems?

The supportive classroom environment dimension includes five items: Student control, student support, academic engagement, explicit quality performance criteria, and self- 
regulation. Key questions addressed in these items include, for instance, is the classroom a socially supportive environment? Are students engaged and on-task? Are criteria for student performance made explicit?

The recognition of difference dimension includes five items: Cultural knowledge, inclusivity, narrative, group identity, and active citizenship. Key questions addressed in these items include, for example, do all students with different backgrounds have an opportunity to participate in the program? Is the teaching principally narrative or is it expository? Does teaching build a sense of community and identity?

The above four dimensions and items of the Productive Pedagogy are summarized and displayed in Figure 1.

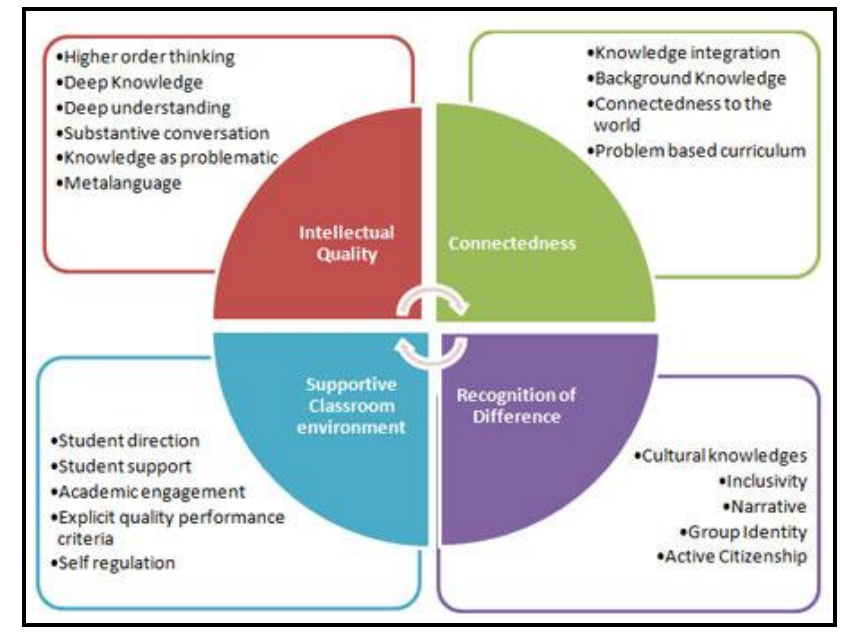

Fig. 1. Productive Pedagogy

\section{RESEARCH METHOD}

The study reported in this article was a part of a survey study which was carried out through questionnaires and follow-up interviews to nine lecturers and 90 mathematics teacher education students, at the Department of Mathematics Education, Indonesia University of Education, Bandung, Indonesia. The study was aimed to investigate the practice of mathematics teacher education. To do so, lecturers and students from nine different courses within the mathematics teacher education program were selected for the purpose of investigation: four courses on mathematics contents, four courses on mathematics didactics-and-pedagogy, and one course on school mathematics. The four mathematics courses include: Calculus, Geometry, Statistics, and Mathematical Analysis. The four mathematics didactics-and-pedagogy courses include: Learning and Teaching Media in Mathematics, Learning and Teaching Strategy in Mathematics, Learning and Teaching Plan in Mathematics, and Research Methodology in Mathematics Education. Finally, the one course concerns selected topics in secondary school mathematics and bridges between mathematics content courses and mathematics didactics-and-pedagogy courses.

The data were collected in two steps. First, the selected lecturers were asked to fill in a questionnaire containing questions about theory and practice of the learning and teaching that they carried out. In addition, ten students from each course were asked to fill in a questionnaire about the implementation of the course. The 17 questions in the questionnaire for lecturers and 18 questions in the questionnaire for students were designed based on the Productive Pedagogy framework. Second, based on the written responses on the questionnaires, the lecturers were interviewed for clarification and for adding more information. The interview for each lecturer lasted for 40-60 minutes.

The data from the questionnaires and interviews were analyzed through two steps. First, we tabulated each written and interview responses from both lecturers and students. Next, we compare responses of both lecturers and students to see similarities, differences, consistence and its correspondences.

\section{RESULTS AND DISCUSSION}

In this section we present results of the data analysis which focused on analyzing three main aspects of the implementation of mathematics teacher education program: Teaching and learning processes, assessment of student performance, and student feedback on the implementation of the learning and teaching as well as the assessment.

\section{A. Learning and Teaching Processes}

The learning and teaching process for the mathematics content courses was in general carried out structurally into three main activities. First, lecturers reviewed prerequisite knowledge or previous relevant contents for learning new mathematics contents. For example, in the Calculus course, to understand the concept of limit of a function, the lecturer reminded students about a graphical representation of a function and about the meaning of the limit of a function intuitively by showing its graphical meaning. Second, in the main activity, lecturers delivered the learning process through addressing definitions, theorems, examples and exercises. Teaching methods used in this activity included lecturing, problem-posing, problem solving, and discussion. For example, in the Geometry course, students were guided to pose statements about properties of, for instance, a parallelogram. Next, the statements that they made should be proved deductively using axioms, definitions, and theorems that have been proved previously. Third, lecturers guided students to draw conclusions about the learning activity and gave tasks for a next meeting.

The learning and teaching process for school mathematics course was carried out as follows. First, students in group were assigned to explain a certain mathematical topic. Other students and the lecturer played a role as audiences or students. Next, based on the presentation, the audiences gave comments, asked questions, or gave suggestions. In this step, the discussion was guided by the lecturer. Third, the lecturer reviewed the presentation, comments and questions, and gave suggestions for improvements. The suggestions included improvements on the correctness of the mathematics contents, and about appropriate approaches, methods, or strategies to deliver the contents. Finally, to give deep knowledge and understanding, the lecturer provided mathematics problems 
inviting the use of higher order thinking and problem solving skills.

For the mathematics didactics-and-pedagogy courses, the learning process proceeded as a combination of approaches similar to the mathematics content courses and to the school mathematics course. In this way, when theoretical knowledge about pedagogy and didactics is needed, the learning process proceeded mainly by lecturing and discussing textbooks and references. When theoretical and practical aspects were addressed, the learning process mainly carried out through student presentation and discussions. The presentation and discussions were mainly based on field observations.

Concerning the use of textbooks, the mathematics contents courses used specific textbooks in the learning and teaching processes. For example, Calculus and Statistics courses used specific textbooks which are used largely in these fields. The school mathematics course did not use any specific textbook, but used relevant mathematics books for schools as a basis for discussion in the learning and teaching processes. A main reason for not using textbooks in this course is, for instance, because the textbooks do not provide didactics and pedagogic aspects on how to deliver the contents of mathematics. The courses on mathematics didactics-and-pedagogy used several relevant textbooks which depend upon needs, but the order of the courses did not necessarily follow step-by-step of the textbooks.

Regarding connections between courses and real-world, the mathematics content courses when appropriate used the theoretical concepts addressed in the courses to solve daily life problems in the form of applications of concepts and of problem solving exercises. For example, Calculus concepts are used to solve daily life and biology problems of, for example, the growth of bacteria, and the speed of a train. Similar to the mathematics content courses, the school mathematics course used relevant concepts to solve daily life problems of, for instance, a ratio of ingredient of a cake recipe. The mathematics didactics-and-pedagogy courses used theoretical knowledge to solve problems at schools via field observation and educational research.

With regard to the use of higher order thinking skills, all mathematics content courses used the skills for understanding concepts (axioms, definitions), proving concepts (theorems) and for solving problems throughout the learning and teaching processes. The school mathematics course used the higher order thinking skills in either delivering contents or solving mathematics problems. The mathematics didactics-andpedagogy courses used the skills for understanding, analyzing, synthesizing and evaluating conceptual and practical knowledge in the form of, for example, writing and presenting papers.

\section{B. Assessment of Student Performance}

In general, to assess student performance, each course used the same criteria and methods established by the university. In particular, even if there were similarities, each course had its own methods of assessments which depend upon the course characteristics and needs. Two main methods of assessments were used for each group of courses: test and non-test methods. Table I presents assessment methods used in the three groups of courses involved in this study.

The main assessment method used in the mathematics content courses was test, in the form of both midterm and final exams. As a kind of formative assessment, several courses, such as Geometry, Math Analysis and Calculus, used quizzes to assess student mastery on specific topics of mathematics. The non-test method in the form of active participation and presentation, even if this method was not frequently used, was also used in the mathematics content courses. The active participation included student response and solutions to problems given by lecturers during the learning and teaching processes. The presentation was usually used for advanced mathematics courses, such as Math Analysis, if the number of students in the class was less than ten students.

The school mathematics course used both test and non-test methods in a balanced manner to assess student performance. The test method was used to see student mastery and problem solving skills on school mathematics problems, whereas the non-test method-in the form of discussion and presentation-was used to see student performance in delivering school mathematics contents to students.

Although the test method, in the form of midterm and final exams, was used to see student performance in mastering theoretical knowledge about didactics and pedagogy, the main assessment method used in the mathematics didactics-andpedagogy courses included non-test, in the form of paper presentation (reporting field observations) and simulation (such as teaching simulation or peer teaching). In other words, the application of theoretical knowledge of didactics-andpedagogy was the main focus of student assessment. In this way, the mastery of theoretical and practical knowledge goes hand-in-hand in a balanced manner in preparing prospective mathematics teacher students.

TABLE I. ASSESSMENT METHODS

\begin{tabular}{|l|l|l|}
\hline \multicolumn{1}{|c|}{ Course group } & \multicolumn{2}{|c|}{ Tssessment methods } \\
\cline { 2 - 3 } & \multicolumn{1}{|c|}{ Nest } & \multicolumn{1}{c|}{ Non-test } \\
\hline Math Contents & $\begin{array}{l}\text { Midterm exam, final } \\
\text { exam, quiz }\end{array}$ & $\begin{array}{l}\text { Course active participation, } \\
\text { and presentation }\end{array}$ \\
\hline School Math & $\begin{array}{l}\text { Midterm exam, final } \\
\text { exam }\end{array}$ & $\begin{array}{l}\text { Discussion and } \\
\text { presentation }\end{array}$ \\
\hline $\begin{array}{l}\text { Math Didactics-and- } \\
\text { Pedagogy }\end{array}$ & $\begin{array}{l}\text { Midterm exam, final } \\
\text { exam }\end{array}$ & $\begin{array}{l}\text { Field observation, } \\
\text { discussion, simulation, } \\
\text { paper work, and } \\
\text { presentation }\end{array}$ \\
\hline
\end{tabular}

\section{Student Feedback on the Implementation of the Learning} and Teaching Processes and the Assessment

Table II presents student feedback on the implementation of the learning and teaching processes carried out at the department of mathematics education, Indonesia University of Education. The first column contains questions. The second, third and fourth columns contain the number of students who answered "yes" and its corresponding percentages. 
STUDENT FEEDBACK ON THE LEARNING AND TEACHING PROCESSES

\begin{tabular}{|l|c|c|c|}
\hline \multicolumn{1}{|c|}{ Questions } & MCc & SMc & MDPc \\
\cline { 2 - 4 } & $\#(\%)$ & $\#(\%)$ & $\#(\%)$ \\
\hline Is this course important for your future? & $31(78)$ & $10(100)$ & $37(93)$ \\
\hline $\begin{array}{l}\text { Does the course content fit with the } \\
\text { syllabus? }\end{array}$ & $35(88)$ & $10(100)$ & $36(90)$ \\
\hline $\begin{array}{l}\text { Do you have an opportunity to involve } \\
\text { actively in the course? }\end{array}$ & $36(90)$ & $10(100)$ & $34(85)$ \\
\hline $\begin{array}{l}\text { Does the course address the theoretical } \\
\text { knowledge about learning and teaching } \\
\text { profoundly? }\end{array}$ & $33(83)$ & $10(100)$ & $28(70)$ \\
\hline $\begin{array}{l}\text { Does the course address conceptual } \\
\text { knowledge about learning and teaching? }\end{array}$ & $37(93)$ & $10(100)$ & $29(73)$ \\
\hline Is a textbook used in this course? & $36(90)$ & $6(60)$ & $10(25)$ \\
\hline $\begin{array}{l}\text { Does the learning and teaching process } \\
\text { of this course always take place within } \\
\text { the classroom? }\end{array}$ & $38(95)$ & $9(90)$ & $25(63)$ \\
\hline $\begin{array}{l}\text { As an addition to textbooks, does this } \\
\text { course use other learning sources? }\end{array}$ & $18(45)$ & $6(60)$ & $27(68)$ \\
\hline $\begin{array}{l}\text { Do you understand about higher order } \\
\text { thinking principle? }\end{array}$ & $24(60)$ & $6(60)$ & $26(65)$ \\
\hline $\begin{array}{l}\text { Do you have an opportunity to develop } \\
\text { higher order thinking? }\end{array}$ & $34(85)$ & $8(80)$ & $32(80)$ \\
\hline $\begin{array}{l}\text { Does this course provide learning and } \\
\text { teaching problems to solve? }\end{array}$ & $35(88)$ & $10(100)$ & $31(78)$ \\
\hline $\begin{array}{l}\text { Does this course integrate different } \\
\text { knowledge into one topic about learning } \\
\text { and teaching? }\end{array}$ & $29(73)$ & $9(90)$ & $32(80)$ \\
\hline $\begin{array}{l}\text { Does this course relate the course } \\
\text { content to daily-life problems? }\end{array}$ & $24(60)$ & $10(100)$ & $35(88)$ \\
\hline $\begin{array}{l}\text { Has this course implemented problem- } \\
\text { based approach in the learning and } \\
\text { teaching process? }\end{array}$ & $25(63)$ & $10(100)$ & $32(80)$ \\
\hline $\begin{array}{l}\text { Has this course implemented project- } \\
\text { based approach in the learning and } \\
\text { teaching process? }\end{array}$ & $0(0)$ & $8(80)$ & $21(53)$ \\
\hline $\begin{array}{l}\text { Has this course implemented } \\
\text { cooperative-learning approach in the } \\
\text { learning and teaching process? }\end{array}$ & $33(83)$ & $10(100)$ & $31(78)$ \\
\hline
\end{tabular}

Concerning the implementation of the learning and teaching processes for the three groups of courses (MCc, SMc, and MDPc), student feedback is in line with lecturers' claims, i.e., the course contents fit with the syllabi $(88 \%, 100 \%$, and $90 \%)$.

Regarding the use of textbooks, this also fits with lecturers claims. The lecturers of mathematics content courses claimed that they used textbooks in the learning and teaching processes which is similar to students' feedback: $90 \%$ of students agreed with this claim. Even if the lecturer of the school mathematics course acknowledged that he did not use any specific textbook, the students considered that mathematics books for schools as textbooks, i.e., 60\% considered that they used textbooks in the course. Although textbooks were not used in the Mathematics Didactics-and-Pedagogy courses, 25\% students considered that they used textbooks, and $68 \%$ students considered that they used other learning sources during the courses.

Regarding the application of theoretical knowledge for solving daily-life problems, $60 \%$ mathematics content courses' students considered that the knowledge has been applied for solving daily-life mathematical problems, $100 \%$ of the school mathematics course's students agreed, and $88 \%$ of the mathematics didactics-and-pedagogy students also agreed.

With regard to the use and the development of higher order thinking skills, student feedback and lecturers claims are also in line. At least $80 \%$ of students in the three groups of courses acknowledged that they have an opportunity to develop their higher order thinking.

In addition to the above results, important notes from student responses concerning the implementation of the learning and teaching processes are, among other things, as follows. First, students expect that the courses should be delivered more comprehensively: Not only addressing factual knowledge, but also dealing with more profound theoretical knowledge. Second, for mathematics content courses, the lectures delivered on slides should be reduced and should return to the use of board - as this way is clearer than only slides. Third, problem solving activities should be provided more extensively to develop higher order thinking skills. Fourth, students expect to get proper paces of lecturing as the students in the classroom have various different abilities in understanding new mathematics contents. Fifth, in one of mathematics didactics-and-pedagogy courses, students expect to have the same opportunity to play a role as teachers in the peer teaching sessions.

Table III presents assessment methods used in the courses according to students. Concerning the use of test methods, lecturers' claims are in line with student feedback. However, for the non-test methods, student feedback in general did not agree with lecturers' claims. For example, only $38 \%$ of students acknowledged that they were assessed by using nontest methods in the mathematics content courses. The difference occurred probably because students' did not recognize that their performance during the learning and teaching processes, such as through active participation and presentation, as a part of the whole assessment. Students might consider that the test method was the main important assessment for them. Another possible reason is that the lecturers might not inform clearly that non-test methods also count for assessments.

TABLE III. STUDENT FEEDBACK ON ASSESSMENTS METHODS IN THE COURSE

\begin{tabular}{|c|c|c|c|}
\hline \multirow{2}{*}{ Questions } & MCc & SMc & MDPc \\
\hline & $\#(\%)$ & $\#(\%)$ & $\#(\%)$ \\
\hline $\begin{array}{l}\text { Are (written) test assessments } \\
\text { administered to assess student } \\
\text { performance in this course? }\end{array}$ & $36(90)$ & $10(100)$ & $36(90)$ \\
\hline $\begin{array}{l}\text { Are non-test assessments administered } \\
\text { to assess student performance in this } \\
\text { course? }\end{array}$ & $15(38)$ & $7(70)$ & $27(68)$ \\
\hline
\end{tabular}

Additional notes on assessment methods from student feedback are, among other things, as follows. First, problems in the written tests were often unpredictable in the sense that they are quite different from problems addressed in the learning and teaching processes. From the perspective of assessment principles, if the problems are really different and outside the scope of course contents, then the problems are not valid - because they could not measure student knowledge and 
skills. Second, students expect to have a more transparence in assessing student performance. Third, students expect to have a more control and a more transparent evaluation on tasks that they did.

\section{CONCLUSION}

From the results described in the previous section, we draw the following conclusions. First, concerning the implementation of the learning and teaching processes, lecturers' claims and student feedback are in general in line, with slight differences. This occurred probably because lecturers in the three groups of courses follow properly the syllabi that they made. However, several important notes to improve the quality of the learning and teaching processes should be taken into account, such as, the less proper use of textbooks, the needs to have more comprehensive development of higher order thinking skills, and the demand to have more application of theoretical knowledge in solving daily life problems. Regarding the assessment methods used for assessing student performance, the use of non-test methods should be more extensive and clearer than before. Also, a more attention to student tasks and active participation should be considered as an important part in the assessment. In addition to these two important results, additional notes from student responses should be considered to improve the practice of mathematics teacher education at the department of mathematics education, Indonesia University of Education. Also, from the results above, we consider that the Productive
Pedagogy proves to be a fruitful framework for investigating the theory and practice of mathematics teacher education.

\section{Acknowledgment}

This study was funded by the Universitas Pendidikan Indonesia (Indonesia University of Education), 2016. We thank lecturers and students, involved in this study, for their active participation.

\section{References}

[1] Presiden Republik Indonesia. (2005). Undang-undang Republik Indonesia Nomor 14 tentang Guru dan Dosen.

[2] Hendayana, S., Suryadi, D., Karim, M. A., Sukirman, Ariswan, Sutopo, Supriatna, A., Sutiman, Santosa, Imansyah, H., Paidi, Ibrohim, Sriyati, S., Permanasari, A., Hikmat, Nurjanah, Joharwaman. (2006). Lesson study: Suatu strategy untuk meningkatkan keprofesionalan pendidik (Pengalaman IMSTEP-JICA). Bandung: UPI Press.

[3] Ruseffendi, E.T. (1991). Pengantar kepada membantu guru mengembangkan kompetensinya dalam pengajaran matematika untuk meningkatkan CBSA. Bandung: Tarsito.

[4] Gore, J. M., Griffiths, T., Ladwig, J. G. (2004). Towards better teaching: productive pedagogy as a framework for teacher education. Teaching and Teacher Education, 20, 375-387.

[5] Queensland School Reform Longitudinal Study (QSRLS). (2002). A guide to productive pedagogies: classroom reflection manual. Brisbane: The State of Queensland (Department of Education). 